\title{
Physicochemical Characteristics and Consumer Acceptance of Bagged Indonesian Green Tea (Camellia sinensis) Formulated with Cinnamon Bark (Cinnamomum burmannii) and Lemon (Citrus limon) Peel
}

\author{
Adinda Kirana, Wenny Bekti Sunarharum* \\ Department of Agricultural Product Technology, Faculty of Agricultural Technology, Universitas Brawijaya, Malang, \\ Indonesia
}

\begin{abstract}
Green tea is a popular functional beverage mostly due to its high antioxidant activity. However, based on preliminary study, the taste such as its bitterness and flavour were somehow disliked by Indonesian consumers, and therefore formulation with other materials such as the addition of cinnamon and lemon peel may bring an advantage. This research was aimed to study the effect of formulation of bagged Indonesian green tea with cinnamon and lemon peel to the physicochemical characteristics of the tea and its consumer acceptance. Evaluation on the effect of different steeping time while brewing those tea formulas was also reported. The formula being investigated was F1, F2, and F3 with green tea: cinnamon: lemon peel at the ratio of 70:15:15, 70:12:18, and 70:9:21, respectively. Tea brewing was performed at $100^{\circ} \mathrm{C}$, followed by a steeping time $(\mathrm{L})$ at 1,3 , and 5 minutes. The results indicated that the addition of more cinnamon and longer steeping time had increased total phenol and antioxidant activity of the brewed tea. Based on the consumer acceptance test, the formula of green tea: cinnamon: lemon peel at 70:15:15 along with 3 minutes steeping time, was generally scored highest for degree of liking but the ratio of 70:12:18 was the most accepted or preferred for aroma. The best treatment was achieved on the ratio of green tea:cinnamon:lemon peel $=70: 12: 18$, under 5 minutes steeping time. The best treatment provided a pH of 5.13, lightness $\left(L^{*}\right)$ at 44.93 , redness $\left(a^{*}\right)$ at -2.50 , yellowness $\left(b^{*}\right)$ at 16.93 , total phenol of $59.82 \mathrm{mgGAE} . \mathrm{g}^{-1}$, and $\mathrm{IC}_{50}$ of $59.39 \mathrm{ppm}$.
\end{abstract}

Keywords: Bagged Indonesian Green Tea, Cinnamon, Lemon Peel, Steeping Time

\section{INTRODUCTION}

The role of tea commodity in the world has been always withstand for its benefits for body requisite. Tea meets with our need for thirst, nutrition, and a particular taste. Indonesia is known as the fifth-largest tea producing country after China, India, Kenya, and Sri Lanka, typically for black, oolong, and green tea [1]. Green tea is one type of tea that can meet the body's nutritional needs because of its antioxidant compounds, such as polyphenols [2]. Green tea is superior comparing to other kinds of tea because green tea doesn't go through an enzymatic oxidation process. Therefore its antioxidant is more active and beneficial for the body [3]. But in addition to these advantages, green tea has a bitter taste that limits its consumption [4]. Our preliminary study also revealed that the bitterness and flavour of Indonesian green tea were somehow disliked by Indonesian consumers. Therefore formulation with other materials may bring benefits in terms of consumer's perspectives.

Out of several ingredients to be added into tea offered through an online survey, the

* Correspondence Address:

Wenny Bekti Sunarharum

Email : wbsunarharum@ub.ac.id

Address : Dept. Agricultural Product Technology, Universitas Brawijaya, Veteran Malang, 65145. majority of consumers (87.5\%) mentioned preference to cinnamon and lemon peel. These two materials were locally and abundantly available in Indonesia. Cinnamon contains cinnamaldehyde, an essential compound that may contribute to sensory characteristics due to its ability to mask off-flavor. The compound is also useful because of its antioxidant properties, which are stronger than other herbs [5]. Different from cinnamon, lemon peels have a low antioxidant (793 ppm) [6]. However, its importance is mostly to alter the sensory character of the final product as previously reported in the study in dragon fruit peel tea and stevia, where $40 \%$ addition of lemon peel had improved its sensory characteristics in terms of taste, aroma, and overall flavour [7].

In the preparation of tea beverages, the dried tea leaves or tea in a bag (bagged tea) are generally brewed using hot water. The tea in contact with water was then allowed to soak for a few minutes to let the flavour and chemical components released in the extract, a processed called as steeping. The brewing process, especially the steeping time, has a significant role in the quality of the flavor and color of the brewed tea [8]. Generally, steeping time for tea was performed at 2-3 minutes [9]. Steeping for 5 minutes is proven to be able to extract $50 \%$ of tea polyphenols. However, longer steeping for 
more than 10 minutes may cause tannin to detach and tea becomes even bitter [10].

Previous research on snake fruit peel herbal tea drinks with the addition of fragrant pandan leaves and cinnamon [11], had reported the importance of ingredients ratio in the formula to the characteristics and quality of the product. This research was aimed to study the effect of the formulation of bagged Indonesian green tea with cinnamon and lemon peel to the physicochemical characteristics of the tea and its consumer acceptance. The effect of different steeping times while brewing was also being investigated.

\section{MATERIALS AND METHODS \\ Materials}

The main materials used in this study were AA quality green tea (Wonosari Malang Tea Plantation), KM quality cinnamon bark (PT. Grencofe Premium Indonesia), and lemon peel (UKM Sari Lemon Gemeli, Batu). Those materials were dried using cabinet dryer and ground into powder (20 mesh).

Analytical materials included $\mathrm{DPPH}$ (SigmaAldrich), Folin-Ciocalteau (Merck), $\mathrm{Na}_{2} \mathrm{CO}_{3}$ (Merck), methanol pro analysis (Smartlab), ethanol pro analysis (Smartlab), gallic acid (Merck). Aquadest, aluminum foil, filter paper, paper teabag, and small paper cups were purchased from a local shop.

\section{Preliminary Study}

Stage one of the preliminary study was an online survey. The online method was used to collect data from 440 correspondents across Indonesia. The survey was aimed to get some insights on which kind of tea and additional ingredients for the tea formula that Indonesian consumers preferred, and thus giving the basis for product development. The participants of this survey were consumers mainly from the age of $17-25$ years old $(82.7 \%)$, men $(71.4 \%)$, Javanese (65\%), and university students (70.2\%). The results were used for formulas that are further tested in this research.

Stage two was determining the percentage of materials in the formulation and the range of steeping time during the brewing process. The author follows the formula used by previous research on green tea with different additional ingredients [12], and modify it by using $50 \%$, $60 \%, 70 \%, 80 \%, 90 \%$ of green tea. The trial was performed by employing limited consumer panellists (10 people) to test sensory acceptance. The range of steeping time during tea brewing was selected based on the Indonesian National Standard (SNI 01-4324-1996) and similar research about steeping time-related to polyphenol compounds $[10,13]$. The result of the preliminary study gave the formula and tea steeping time used in the research.

\section{Research Design}

The study was conducted using a factorial randomized block design with two factors. The first factor was the ratio of green tea: cinnamon:lemon peel with three formulations, i.e. F1 (70:15:15), F2 (70:12:18), and F3 (70:9:21), in percentage. The second factor was three levels of steeping time (L) at 1,3 , and 5 minutes. The analysis was conducted in triplicates. The best treatment was determined using the Multiple Attribute method by Zeleny [13].

\section{Tea Preparation}

Green tea powder, cinnamon powder, and lemon peel powder (20 mesh) were weighed according to the formula and bagged in a paper teabag ea. $\pm 2 \mathrm{~g}$. This bagged tea was further brewed with hot water $\left(100^{\circ} \mathrm{C}\right)$ before further steeping for certain times based on the designed treatments.

\section{Physicochemical Analysis}

All samples (dry tea formula and brewed tea) were analysed for color by measuring Lightness $\left(L^{*}\right)$, redness $\left(a^{*}\right)$, and yellowness $\left(b^{*}\right)$ by using color reader (CR-10) [14], $\mathrm{pH}$ by using $\mathrm{pH}$ meter (Senz pH) [15], and moisture content by using AOAC gravimetric method [16], total phenol [17] and antioxidant activity [18]. For total phenol analysis [17], the sample $(0.5 \mathrm{~mL})$ was added to a $10 \mathrm{~mL}$ Folin Ciocalteau 10\% solution, then incubated for 5 minutes at room temperature $\left( \pm 28^{\circ} \mathrm{C}\right)$. Then, $2 \mathrm{~mL}$ of $\mathrm{Na}_{2} \mathrm{CO}_{3} 7.5 \%$ added before further homogenization and incubation for 30 minutes in the dark. The absorbance was measured at a maximum wavelength of $750 \mathrm{~nm}$. Total phenol levels were expressed as gallic acid equivalent (mgGAE. ${ }^{-1}$ ).

The antioxidant activity was measured by $\mathrm{IC}_{50}$ analysis [18], where $2 \mathrm{~mL}$ samples were reacted with $2 \mathrm{~mL}$ DPPH $0.2 \mathrm{mM}$ and homogenized. The mixtures was further incubated at room temperature $\left( \pm 28^{\circ} \mathrm{C}\right)$ in the dark for 30 minutes. Absorbance were measured using a spectrophotometer (Thermo Scientific Genesys 110s UV-Vis) at a maximum wavelength of 517 $\mathrm{nm}$.

\section{Consumer Acceptance Test}

Consumer acceptance of the brewed tea was evaluated by using the hedonic method [19]. For 
this purpose, as many as 140 consumer panellists were employed to evaluate 9 samples for the degree of liking. Panellists were asked to rate six parameters i.e. color, aroma, taste, aftertaste, appearance, and overall liking from 1 to 9 .

\section{Statistical Data Analysis}

Data was collected and tabulated in Microsoft Excel 2013 software (Microsoft Corp., Redmond, Washington, USA). Analysis of Variance (ANOVA) and further post-hoc analysis was performed using Minitab 17 statistical software (Minitab Inc., State College, Pennsylvania, USA).

\section{RESULTS AND DISCUSSION}

\section{Evaluation on Raw Materials}

Based on Table 1, it can be seen that each material has different chemical and physical characteristics. It should be noted that the differences are not only solely due to the different material but could also be the origin of raw materials, storage conditions, humidity of the surrounding air, post-harvest processing, particle size, harvesting process, the duration of the process before being packed, the type of machine/tool during the process, the method and the purpose of extraction, type of quality, method of drying and varieties of material [20].

The different characteristics are due to the compounds contained in the material. Lemon peels contain organic acids, such as citric acid, malic acid, oxalic acid, and malonic acid [21]. Cinnamon contains cinnamic acid, cinnamid, vanillic acid, gallic acid, protocatechuic acid, caffeic acid, ferulic acid, p-coumaric [22]. Green tea contains several organic acids, including ascorbic acid, malic acid, oxalate, gallate, chlorogenic, and succinate [23].

Table 1. Characteristics of teabag raw materials

\begin{tabular}{cccc}
\hline Parameter & Green Tea & Cinnamon & Lemon Peel \\
\hline water content (\%) & $7.82 \pm 0.34$ & $8.88 \pm 0.55$ & $9.67 \pm 0.35$ \\
$\mathrm{~L}^{*}$ & $47.30 \pm 0.95$ & $53.73 \pm 0.83$ & $70.77 \pm 2.80$ \\
$\mathrm{a}^{*}$ & $-2.27 \pm 0.15$ & $8.97 \pm 0.51$ & $1.60 \pm 0.10$ \\
$\mathrm{~b}^{*}$ & $11.57 \pm 0.74$ & $20.73 \pm 0.59$ & $30.67 \pm 0.21$ \\
$\mathrm{pH}$ & $5.23 \pm 0.15$ & $5.17 \pm 0.06$ & $4.43 \pm 0.12$ \\
\hline $\begin{array}{c}\text { Total phenol } \\
\left(\mathrm{mgGAE} . \mathrm{g}^{-1}\right)\end{array}$ & $257.37 \pm 0.55$ & $81.93 \pm 0.29$ & $30.87 \pm 0.24$ \\
\hline $\begin{array}{c}\text { Antioxidant } \\
\text { activity IC }\end{array}$ & $16.37 \pm 0.21$ & $54.54 \pm 0.48$ & $294.18 \pm 4.55$ \\
\hline Note: & &
\end{tabular}

Note: Data mean \pm standard deviation $(n=3)$

\section{Formulation of Materials}

Based on Table 2, it can be seen that the higher the amount of lemon peel would increase the water content. In a less optimal drying process, water will still be available in the albedo part, therefore the water content is still quite high. Albedo's function is to supply nutrients and water from trees [24]. It is also known that lightness $\left(\mathrm{L}^{*}\right)$, and yellowness $\left(\mathrm{b}^{*}\right)$ are increased while decreasing redness $\left(a^{*}\right)$. The increase in $L^{*}$ and $b^{*}$ value are thought due to the degradation of chlorophyll pigments into carotenoids and $\beta$ cryptoxanthin during fruit ripening resulting in yellowish color and lightness [25]. The a* value decreased with the reduction of cinnamon suggested due to the loss of darkness contribution such as from cinnamaldehyde and anthocyanin [11].

Table 2. Characteristics of dry teabag formulations

\begin{tabular}{|c|c|c|c|}
\hline \multirow[t]{2}{*}{ Parameter } & \multicolumn{3}{|c|}{$\begin{array}{c}\text { Treatment Ratio of Green Tea:Cinnamon: } \\
\text { Lemon Peel (\%) }\end{array}$} \\
\hline & F1 (70:15:15) & F2 (70:12:18) & $F 3(70: 9: 21)$ \\
\hline $\begin{array}{c}\text { Water } \\
\text { content (\%) }\end{array}$ & $8.80 \pm 0.79$ & $9.34 \pm 0.46$ & $9.99 \pm 0.29$ \\
\hline$L^{*}$ & $46.83 \pm 1.04^{c}$ & $49.17 \pm 0.81^{b}$ & $52.33 \pm 0.57^{a}$ \\
\hline$a^{*}$ & $0.48 \pm 0.03^{\mathrm{a}}$ & $0.38 \pm 0.03^{b}$ & $-0.20 \pm 0.00^{c}$ \\
\hline$b^{*}$ & $14.63 \pm 0.21^{b}$ & $15.70 \pm 0.53^{\mathrm{ab}}$ & $16.90 \pm 0.96^{a}$ \\
\hline $\mathrm{pH}$ & $4.93 \pm 0.06$ & $4.87 \pm 0.05$ & $4.80 \pm 0.10$ \\
\hline $\begin{array}{l}\text { Total phenol } \\
\left(\mathrm{mgGAE} . \mathrm{g}^{-1}\right)\end{array}$ & $\begin{array}{c}236.10 \pm \\
0.95^{\mathrm{a}} \\
\end{array}$ & $225.46 \pm 0.73^{b}$ & $\begin{array}{c}192.76 \pm \\
0.82^{\mathrm{c}} \\
\end{array}$ \\
\hline $\begin{array}{l}\text { Antioxidant } \\
\text { activity IC } C_{50} \\
(\mathrm{ppm})\end{array}$ & $16.46 \pm 0.30^{c}$ & $17.61 \pm 0.10^{b}$ & $19.01 \pm 0.44^{\mathrm{a}}$ \\
\hline
\end{tabular}

Note: Data mean \pm standard deviation $(n=3)$. Numbers accompanied by different notations showed significant differences $(\alpha=0.05)$

Cinnamon contains cinnamic acid, gallic acid [22], cinnamaldehyde, eugenol $>80 \%$, and others [26]. These acidic compounds can play a role in the $\mathrm{pH}$ of cinnamon and affect formulation $\mathrm{pH}$. Those acidic compounds also have a role with polyphenols such as epigallocatechin gallate (EGCg) in green tea, terpineol in cinnamon [27], and D-limonene in lemon peel [28]. Table 2 indicates the decrease in total phenol and antioxidant activity when more lemon peel added. It is suggested due to the lower amount of total phenols and antioxidant activity in the lemon peel as compared to that of cinnamon. Previous research had also reported that lemon peel has a week antioxidant level [29].

\section{Evaluation on the Brewed Tea}

The brewed tea was analysed for color, $\mathrm{pH}$, total phenol, $\mathrm{IC}_{50}$ values, and the level of panelist preference.

\section{Color Analysis}

Results showed that the formulation of green tea, cinnamon and lemon peel, steeping time, and interactions between two factors has a significant effect $(\alpha=0.05)$ on lightness $\left(L^{*}\right)$, redness $\left(a^{*}\right)$ but not on yellowness $\left(b^{*}\right)$ of brewed tea. Table 3 showed that higher lemon peel proportion would increase $L^{*}$ and $b^{*}$ value 
of brewed tea while decreasing a* value. The $L^{*}$ value increase with the reduction in the proportion of cinnamon due to the loss of red color and lightness contribution from cinnamon. The results also showed that brewed tea has more $b^{*}$ than $a^{*}$ value, suggested due to more carotene compound that contributes to the yellow color while chlorophyll, carotene, pheophytin, xanthophyll, and pheophorbide in green tea and cinnamon might contribute to $a^{*}$ value [30].

This study had also indicated that the longer steeping time increased the $L^{*}, a^{*}$ and $b^{*}$ value, suggested due to more compounds extracted and interacted with others. The high temperature might result in color change due to chlorophyll degradation into pheophytin, which looks grayish-green [31].

\section{2. $\mathrm{pH}$ Measurement}

The results of $\mathrm{pH}$ measurement of the samples are provided in Table 3. It can be seen that proportion of green tea, cinnamon, and lemon peel, steeping time had a significant effect on the $\mathrm{pH}$ of brewed tea $(\alpha=0.05)$, but the interaction between two factors was not significant $(\alpha=0.05)$. The higher proportion of lemon peel in a teabag and longer steeping time was found to decrease the $\mathrm{pH}$ of brewed tea. It is suggested due to the contribution of some components in teabag materials, such as organic acid (citric acid) in lemon peel [21], and the more acids dissolved [32].

\section{Total Phenol}

Table 3 showed the result of total phenol analysis. The ANOVA indicated that the proportion of green tea, cinnamon, and lemon peel, steeping time, and interaction between the two factors had a significant effect $(\alpha=0.05)$ on total phenols of brewed tea. It revealed that the higher proportion of cinnamon tends to increase the total phenolic content of brewed tea (Table 3) since cinnamon has higher phenol than lemon peel (Table 1). One of important phenolic compounds in cinnamon is eugenol [27]. The increase in steeping time is found to increase total phenol. Again, this could be explained due to more extraction of phenolic compounds during steeping until it reaches the optimum point, where no more compounds can be extracted.

\section{Antioxidant Activity}

Antioxidant activity of the brewed tea (Table 3) expressed as $I C_{50}$ was found to be significantly different ( $\alpha=0.05$ ) as influenced by different tea formulation and steeping time. The $\mathrm{IC}_{50}$ ranged approximately from 47.59 up to 115.49 ppm. Table 3 showed that a higher proportion of cinnamon tends to increase the antioxidant activity of brewed tea (or the decrease in $I C_{50}$ value). It is suggested due to the incorporation of several phenolic compounds, which are an active antioxidant from cinnamon such as cinnamaldehyde, cinnamyl acetate, and benzyl benzoate to the extract. The longer the steeping time was also found to decrease the $\mathrm{IC}_{50}$ of the corresponding brew, meaning that the antioxidant activity level was higher. The three formula (F1, F2, F3) showed a similar trend where the 5 minutes extraction time could increase antioxidant activity into two-fold, as shown by a decrease in $\mathrm{IC}_{50}$ up to almost half as compared to the 1-minute extraction or steeping time. Longer time allows more phenols and antioxidant compounds to be extracted into the brewed/infused tea.

Table 3. Characteristics of the brewed tea

\begin{tabular}{|c|c|c|c|c|c|c|}
\hline \multirow[b]{2}{*}{ Treatment } & \multicolumn{6}{|c|}{ Parameter } \\
\hline & $\mathbf{L}^{*}$ & $a *$ & b* & $\mathrm{pH}$ & $\begin{array}{l}\text { Total phenol } \\
\left(\mathrm{mgGAE}^{-1}\right)^{-1}\end{array}$ & $\mathrm{IC}_{50}(\mathrm{ppm})$ \\
\hline F1L1 & $54.00 \pm 1.93^{\mathrm{ab}}$ & $-3.30 \pm 0.20^{c}$ & $8.30 \pm 0.82$ & $5.33 \pm 0.06$ & $38.36 \pm 2.90^{\mathrm{e}}$ & $81.87 \pm 4.67^{b c}$ \\
\hline F1L2 & $41.63 \pm 1.263^{\mathrm{e}}$ & $-2.63 \pm 0.31^{b}$ & $13.07 \pm 0.57$ & $5.23 \pm 0.06$ & $60.97 \pm 0.69^{\mathrm{ab}}$ & $68.07 \pm 1.57^{d}$ \\
\hline F1L3 & $35.27 \pm 3.37^{f}$ & $-0.57 \pm 0.06^{a}$ & $15.40 \pm 0.89$ & $5.17 \pm 0.12$ & $62.43 \pm 0.15^{a}$ & $47.59 \pm 1.30^{f}$ \\
\hline F2L1 & $54.33 \pm 3.26^{\mathrm{ab}}$ & $-3.90 \pm 0.30^{d}$ & $9.03 \pm 0.57$ & $5.30 \pm 0.00$ & $36.20 \pm 0.48^{f}$ & $85.64 \pm 1.70^{b}$ \\
\hline F2L2 & $48.00 \pm 0.36^{\mathrm{cd}}$ & $-2.90 \pm 0.27^{b c}$ & $16.87 \pm 1.20$ & $5.17 \pm 0.06$ & $55.98 \pm 0.42^{c}$ & $79.89 \pm 0.48^{c}$ \\
\hline F2L3 & $44.93 \pm 3.87^{\mathrm{de}}$ & $-2.50 \pm 0.27^{b}$ & $16.93 \pm 1.60$ & $5.13 \pm 0.06$ & $59.82 \pm 0.20^{b}$ & $59.39 \pm 1.67^{e}$ \\
\hline F3L1 & $55.57 \pm 2.58^{a}$ & $-6.03 \pm 0.64^{e}$ & $10.43 \pm 0.71$ & $5.27 \pm 0.06$ & $35.41 \pm 0.67^{f}$ & $115.49 \pm 4.38^{\mathrm{a}}$ \\
\hline F3L2 & $50.90 \pm 2.52^{b c}$ & $-3.17 \pm 0.21^{c}$ & $17.23 \pm 1.70$ & $5.13 \pm 0.06$ & $39.38 \pm 0.38^{\mathrm{e}}$ & $81.27 \pm 2.94^{b c}$ \\
\hline F3L3 & $48.73 \pm 1.03^{\mathrm{cd}}$ & $-2.53 \pm 0.31^{b}$ & $17.47 \pm 0.97$ & $5.00 \pm 0.10$ & $47.63 \pm 0.77^{d}$ & $66.56 \pm 2.32^{d}$ \\
\hline
\end{tabular}

Note: F1= green tea: cinnamon: lemon peel (70:15:15), F2 (70:12:18) and F3 (70:9:21), L1= steeping time at 1 minute, L2 = 3 minutes, $L 3=5$ minutes, Data mean \pm standard deviation $(n=3)$. Numbers accompanied by different notations showed significant differences $(\alpha=0.05)$ 


\section{Consumer Acceptance}

In the sensory evaluation, there were six parameters (color, aroma, taste, appearance, aftertaste, and overall liking) scored by 140 consumer panelists. Score from 1 to 9 was used in the test to know the degree of liking or consumer acceptance. The result of this test can be seen in Table 4, where the formula of green tea: cinnamon: lemon peel at 70:15:15 along with 3 minutes steeping time (F1L2) was scored highest for all parameters except for aroma. The consumers preferred green tea: cinnamon: lemon peel at 70:12:18 combined with 5 minutes steeping time (F2L3) for aroma. It is more likely that consumer's preference was driven by the aroma of the brew, where lemony aroma can offer a balance with a strong cinnamon aroma. The more lemon peel adds more acidity and lemon notes responsible for creating balance and reduce the dominance of cinnamon aroma. Moreover, the longer steeping time of 5 minutes was suggested to increase the extraction of aromatic compounds, essential oils, or flavour compounds from cinnamon and lemon peel into the brew.

Table 4. Panelists' preference level for the brewed tea

\begin{tabular}{ccccccc}
\hline & \multicolumn{6}{c}{ Parameter } \\
\cline { 2 - 7 } Treatment & \multicolumn{6}{c}{ color aroma } \\
& & & \multicolumn{5}{c}{ taste after-taste $\begin{array}{c}\text { appear overall } \\
\text { ance }\end{array}$} & liking \\
\hline F1L1 & 5.83 & 5.54 & 5.64 & 5.72 & 5.97 & 5.87 \\
F1L2 & $\mathbf{6 . 2 1}$ & 5.79 & $\mathbf{6 . 3 2}$ & $\mathbf{6 . 1 4}$ & $\mathbf{6 . 1 2}$ & $\mathbf{6 . 9 9}$ \\
F1L3 & 5.91 & 5.89 & 5.34 & 5.25 & 6.06 & 5.82 \\
F2L1 & 6.03 & 5.62 & 5.60 & 5.64 & 6.01 & 5.90 \\
F2L2 & 6.08 & 5.82 & 5.53 & 5.44 & 5.84 & 5.91 \\
F2L3 & 5.83 & $\mathbf{5 . 9 5}$ & 5.59 & 5.46 & 5.72 & 5.84 \\
F3L1 & 5.50 & 5.41 & 5.56 & 5.66 & 5.43 & 5.71 \\
F3L2 & 5.98 & 5.59 & 5.29 & 5.48 & 6.03 & 5.72 \\
F3L3 & 5.97 & 5.94 & 5.59 & 5.40 & 5.96 & 5.80 \\
\hline
\end{tabular}

Note: F1= green tea: cinnamon: lemon peel (70:15:15), F2 (70:12:18) and F3 (70:9:21), L1= steeping time at 1 minute, $\mathrm{L} 2=3$ minutes, $\mathrm{L} 3=5$ minutes. Bold numbers indicate the highest value of liking (most preferred)

\section{Best Formula and Steeping Time Selection}

The best treatment in this research (formula and steeping time) is determined by the Multiple Criteria Decision-Making method [14], where all attributes are equally important. The involvement of all these attributes caused the ranking of each treatment to be different so that a different effectiveness index was also obtained. The determination of the best treatment can be calculated from all parameters measured i.e. physical, chemical, and organoleptic parameters with the lowest density distance.

The best treatment with the lowest value of the effectiveness index 0.56 was the F2L3, which is a formula of green tea: cinnamon: lemon peel of 70:12:18, combined with 5 minutes steeping time. The physical and chemical quality characteristics of the best tea formula is provided in Table 5.

Table 5. Characteristics of the best treatment(brewed tea)

\begin{tabular}{ccc}
\hline Parameter & $\begin{array}{c}\text { Best Treatment } \\
\text { (F2L3) }\end{array}$ & $\begin{array}{c}\text { Green } \\
\text { Tea }\end{array}$ \\
\hline $\mathrm{pH}$ & 5.13 & - \\
Color $\left(\mathrm{L}^{*} \mathrm{a}^{*} \mathrm{~b}^{*}\right.$ value) & $44.93^{*}-2.50^{*} 16.93^{*}$ & - \\
$\begin{array}{c}\text { Total phenol (mgGAE.g } \\
\text { Ant })\end{array}$ & 59.82 & 68.55 \\
$\begin{array}{c}\text { Antioxidant activity }\left(\mathrm{IC}_{50}\right) \\
(\mathrm{ppm})\end{array}$ & 59.39 & 46.03 \\
\hline
\end{tabular}

The chosen formula and steeping time has lower total phenol and antioxidant activity than pure green tea (Table 5), but the organoleptic characteristics were suggested to be better due to the incorporation of cinnamon and lemon peel. The addition of these two ingredients had improved flavour, in this case, cinnamon and lemon, giving sweetness, warm and lemony characteristics of the tea. The balance of these characters had contributed to an increase in consumer acceptance.

\section{CONCLUSION}

The incorporation of cinnamon and lemon peel in different proportion, as well as steeping time, had a significant influence on physical, chemical and organoleptic properties of brewed green tea to some extent, such as the effect on lightness $\left(L^{*}\right)$, redness $\left(a^{*}\right)$, yellowness $\left(b^{*}\right), p H$, total phenol, and antioxidant activity value of $\mathrm{IC}_{50}$. The interaction between the two factors or treatments is also affecting some of the parameters. The changes in brewed tea properties are suggested due to different compositions and interactions between components extracted during steeping. The formula of green tea: cinnamon: lemon peel at 70:15:15 along with 3 minutes steeping time was the most preferred by consumers, but it was not chosen as the best formula or treatment. The best treatment was the ratio of green tea:cinnamon:lemon peel $=70: 12: 18$, under 5 minutes steeping time, that was chosen by considering not only consumer degree of liking but also other physicochemical parameters. The result had indicated the potential of the current formula as a functional product. However, further research will be required to justify the benefits and functionality of the product.

\section{REFERENCES}

[1] Chang, K. 2015. World tea production and trade: current and future development. 
Food and Agriculture Organization of The United Nations. Rome.

[2] Balittri, J.T. 2013. Kandungan senyawa kimia pada daun teh. Warta Penelitian Dan Pengembangan Tanaman Industri.19(3). 12-16.

[3] Sinija, V.R., H.N. Mishra. 2008. Green tea: health benefits. J. Nutr. Environ. Med. 17(4). 232-242.

[4] Kusanto, Y.S. 2013. Pengaruh variasi konsentrasi air seduhan teh hijau terhadap sifat fisikokimia dan organoleptik permen jelly teh hijau (Camellia sinensis). PhD Thesis. Faculty of Agricultural Technology, Universitas Katolik Widya Mandala Surabaya.

[5] Ravindran, P.N., K.N. Babu, M. Shylaja. 2004. Cinnamon and cassia the genus Cinnamomum: medicinal and aromatic plants-industrial profiles. CRC Press. Washington DC.

[6] Asendy, D.A., I.W.R. Widarta, K.A. Nocianitri. 2018. Pengaruh waktu maserasi terhadap aktivitas antioksidan ekstrak kulit buah jeruk lemon (Citrus limon Linn). Jurnal Ilmu dan Teknologi Pangan. 7. 102-109.

[7] Shofiati, A., M.A.M. Andriani, C. Anam. 2014. Kajian kapasitas antioksidan dan penerimaan sensoris teh celup kulit buah naga (pitaya fruit) dengan penambahan kulit jeruk lemon dan stevia. Jurnal Teknosains Pangan. 3(2). 5-13.

[8] Ramlah, R. 2017. Penentuan suhu dan waktu optimum penyeduhan daun teh hijau (Camellia sinensis L) $\mathrm{P}+2$ terhadap kandungan antioksidan kafein, tannin dan katekin. PhD Thesis. Universitas Islam Negeri Alauddin Makassar.

[9] McAlpine, M.D., W.E. Ward. 2016. Influence of steep time on polyphenol content and antioxidant capacity of black, green, rooibos, and herbal teas. Beverages. 2(3). 17.

[10] Cleverdon, R., Y. Elhalaby, M.D. McAlpine, W. Gittings, W.E. Ward. 2018. Total polyphenol content and antioxidant capacity of tea bags: Comparison of black, green, red Rooibos, chamomile and peppermint over different steep times. Beverages. 4(1). 15.

[11] Anjani, P.P., S. Andrianty, T.D. Widyaningsih. 2015. Pengaruh penambahan pandan wangi dan kayu manis pada teh herbal kulit salak bagi penderita diabetes. Jurnal Pangan dan Agroindustri. 3(1). 203-214.
[12] Prasetyo, E. 2013. Formula bubuk "Teajes" instan pada filtrat teh hijau (Camellia sinensis) dan filtrat jahe (Zingiber officinale) dengan penambahan filtrat kayu secang (Caesalpinia sappan). PhD Thesis. Universitas Brawijaya. Malang.

[13] Zeleny, M. 1982. Multiple criteria decision making. McGraw-Hill. New York City.

[14] Juncai, H., H. Yaohua, H. Lixia, G. Kangquan, T. Satake. 2015. Classification of ripening stages of bananas based on support vector machine. Int. J. Agr. Biol. Eng. 8(6). 99-103.

[15] Angelia, I.O. 2017. Kandungan pH, total asam tertitrasi, padatan terlarut dan vitamin C pada beberapa komoditas hortikultura $(\mathrm{pH}$ content, total acidified acid, dissolved solids and vitamin $\mathrm{c}$ in some horticultural commodities). J. Agritech Sci. (JASC). 1(2). 68-74.

[16] AOAC. 1997. Official methods of analysis: association of official analytical chemist. Association of Official Analytical Chemists Inc. Arlington.

[17] Sharma, G.N., S.K. Dubey, N. Sati, J. Sanadya. 2011. Phytochemical screening and estimation of total phenolic content in Aegle marmelos seeds. Int. J. Pharm. Clin. Res. 2(3). 27-29.

[18] Molyneux, P. 2004. The use of the stable free radical diphenylpicrylhydrazyl (DPPH) for estimating antioxidant activity. Songklanakarin J. Sci. Technol. 26(2). 211219.

[19] SSP. 2020. The 9-Point Hedonic Scale. Available at: https://www.sensorysociety. org/.

[20] Nwoseu, F., A. Kareem. 2015. Production of citric acid from lemon and cassava waste peels. Nigerian J. Mater. Sci. Eng. 6(1). 1-7.

[21] Clements, R.L. 1964. Organic acids in citrus fruits. I. Varietal differences a.J. Food Sci. 29(3). 276-280.

[22] Emilda, E. 2018. Efek senyawa bioaktif kayu manis cinnamomum burmanii nees ex. Bl.) Terhadap diabetes melitus: kajian pustaka. Jurnal Fitofarmaka Indonesia. 5(1). 246-252.

[23] Chatuverdula, V.S.P., R.I.S. Miguel, I. Prakash. 2012. Chemical constituents from polar fraction of Rubus suavissimus. Organic Chem Current Res. 1(1). DOI: 10.4172/21610401.1000101.

[24] Ekaputri, F. 2018. Pengaruh perbandingan kulit dan sari lemon dan konsentrasi kayu manis terhadap karakteristik selai lemon 
(Citrus limon burm $f$.) secara organoleptik. Master Thesis. Universitas Pasundan.

[25] Conesa, A., F.C. Manera, J.M. Brotons, J.C. Fernandez-Zapata, I. Simón, S. Simón-Grao, M. Alfosea-Simón, J.M., Nicolás, J.M. Valverde, F. García-Sanchez. 2019. Changes in the content of chlorophylls and carotenoids in the rind of Fino 49 lemons during maturation and their relationship with parameters from the CIELAB color space. Scientia Horticulturae. 243. 252-260.

[26] Nabavi, S.F., A. Di Lorenzo, M. Izadi, E. Sobarzo-Sánchez, M. Daglia, S.M. Nabavi, 2015. Antibacterial effects of cinnamon: from farm to food, cosmetic and pharmaceutical industries. Nutrients. 7(9). 7729-7748.

[27] Praseptiangga. D., S.E. Invicta, L.U. Khasanah. 2019. Sensory and physicochemical characteristics of dark chocolate bar with addition of cinnamon (Cinnamomum burmannii) bark oleoresin microcapsule. J. Food Sci. Technol. 56(9). 4323-4332.

[28] Moosavy, M., P. Hassanzadeh, E. Mohammadzadeh, R. Mahmoudi, S. Khatibi, K. Mardani. 2017. Antioxidant and antimicrobial activities of essential oil of lemon (Citrus limon) peel in vitro and in a food model. J. Food Qual. Hazards Control, 4(2). 42-48.

[29] Juanda, D. 2015. Penetapan kadar total fenol dan aktivitas antioksidan dari jus buah lima spesies jeruk (Citrus sp.). Jurnal farmasi Galenika. 2(1). 36-42.

[30] Andarini, F., S. Yasni. 2018. Pengembangan minuman fungsional dari ekstrak kulit mundar. Jurnal Teknologi dan Industri Pangan. 29(1). 49-57.

[31] Kusmita, L., I. Puspitanningrum, L. Limantara. 2015. Identification, isolation and antioxidant activity of pheophytin from green tea (Camellia sinensis (L.) Kuntze). Procedia Chem. 14(14). 232-238.

[32] Ibrahim, A.M., Y. Yunianta, F.H. Sriherfyna. 2014. Pengaruh suhu dan lama waktu ekstraksi terhadap sifat kimia dan fisik pada pembuatan minuman sari jahe merah (Zingiber officinale var. Rubrum) dengan kombinasi penambahan madu sebagai pemanis. Jurnal Pangan dan Agroindustri. 3(2). 530-541. 